Kansas State University Libraries

New Prairie Press

\title{
PREVALENCE RATE DIFFERENCES BASED ON HERDMATE COMPARISONS
}

Jerome M. Sacks

Randall C. Cutlip

Amy L. Weaver

Howard D. Lehmkuhl

See next page for additional authors

Follow this and additional works at: https://newprairiepress.org/agstatconference

Part of the Agriculture Commons, and the Applied Statistics Commons

\section{(c) (1) $\Theta($}

This work is licensed under a Creative Commons Attribution-Noncommercial-No Derivative Works 4.0 License.

\section{Recommended Citation}

Sacks, Jerome M.; Cutlip, Randall C.; Weaver, Amy L.; and Lehmkuhl, Howard D. (1992). "PREVALENCE RATE DIFFERENCES BASED ON HERDMATE COMPARISONS," Conference on Applied Statistics in Agriculture. https://doi.org/10.4148/2475-7772.1393

This is brought to you for free and open access by the Conferences at New Prairie Press. It has been accepted for inclusion in Conference on Applied Statistics in Agriculture by an authorized administrator of New Prairie Press. For more information, please contact cads@k-state.edu. 
Author Information

Jerome M. Sacks, Randall C. Cutlip, Amy L. Weaver, and Howard D. Lehmkuhl

This is available at New Prairie Press: https://newprairiepress.org/agstatconference/1992/proceedings/5 
PREVALENCE RATE DIFFERENCES BASED ON HERDMATE COMPARISONS

Jerome M. Sacks, PhD; ${ }^{1}$ Randall C. Cutlip, DVM; Amy L. Weaver, MS and Howard D. Lehmkuhl, PhD

National Animal Disease Center, Agricultural Research Service, United States Department of Agriculture, P.O. Box 70, Ames, IA 50010

1 Hines VA Hospital, CSPCC, P.O. Box 5000, Hines, IL, 60141-5000

\author{
Abstract
}

A non-random survey of ovine progressive pneumonia (OPP) seropositive prevalence rates among 16,827 sheep in 29 states in the United states revealed large breed differences, a higher prevalence rate among older sheep and an unexplainable female rate that was more that three times the male rate. The herdmate comparison procedure, successfully used in evaluating dairy bulls, was adapted to compare the prevalence of a breed to the rate of its herdmates within herds. Iikewise, sex and age differences in OPP prevalence were compared within herds that contained animals of both sexes and several ages. Using herdmate comparisons, breed and age differences in OPP prevalence remained but the sex difference disappeared. 


\section{Introduction}

Domestic animal morbidity surveys often analyze data from available convenient sources such as abattoirs or cooperating farms to evaluate the relative disease rates for factors such as breed. Unfortunately, these comparisons are based on a non-random sample. In a random sample, animals of any specific category would not tend to be associated with any particular geographical location or management and any observed differences associated with members of a category, such as breed differences in disease rate, would reflect genuine category differences. In a non-random sample, a category such as breed might be associated with specific locations or managements and the seeming differences in disease rates may in fact be a reflection of the particular location or management. For example, two breeds with very different sample prevalence rates may come from different geographical regions. If so, the apparent breed variation in disease susceptibility may actually be a reflection of geographical diversity i.e. breed and herd factors may be confounded. Statistical adjustments, by the use of covariates, are available but they are based on assumptions whose validity may not be known. The investigator may be faced with a choice between a suspect comparison or an adjustment of unproven merit.

Modern breeding programs face the same dilemma in sire evaluation. Sire performance is measured by daughter milk yield but the daughters are not randomly distributed among herds. The solution is to use herdmate comparisons to evaluate the daughter's milk production (Robertson and Rendel, 1954; Henderson et al, 1954). For domestic animals, the farm or herd represents a common environment within which other factors can be compared. Thus, a dairy cow's milk production is routinely measured by the deviation of her milk yield from the average yield of her herdmates in order to estimate her yield potential free from confounding with farm factors. Sire evaluation by means of dairy cow herdmate comparisons has been amply validated by the success of AI dairy breeding (USDA-DHIA Modified Contemporary Comparison, 1976).

This paper presents a prevalence estimation procedure for situations where random sampling is not possible. Its use is illustrated with data from a nationwide survey of ovine progressive pneumonia to analyze age, breed and sex differences in disease prevalence.

\section{MATERIALS AND METHODS}

Estimation of average prevalence deviation from herdmates

The procedure for comparing prevalence rates will be presented using breed as the category of interest. The goal will be to estimate the average deviation of each breed from overall mean prevalence. The estimation procedure consists of 4 steps.

(1) For a particular breed in the survey, select only those herds that contain both the index breed and other animals of other breeds.

(2) For each qualifying herd, compute the average prevalences (P1) for the index group and herdmates (P2).

(3) For each farm compute the difference (HD)

$$
\mathrm{HD}=\mathrm{P} 1-\mathrm{P} 2 \text {. }
$$

farms.

(4) Compute the mean and standard error of HD over selected 


\section{Data Description}

Sera were collected from sheep in a 29 state study of ovine progressive pneumonia (OPP) seropositivity. Individual sheep were identified by owner, breed, age, sex and geographical region. The data represented all the herd owners willing to cooperate in a multi-year survey that had as its goal the reduction of ovine progressive pneumonia prevalence. Details of this study in sheep and a similar study in goats have been presented in separate reports (Cutlip et al, 1990,; Cutlip et al, 1991).

\section{RESULTS}

A study of OPP among 16,827 sheep from 164 farms in 29 states in the United States examined breed, age and sex differences in OPP prevalence (Table 1). Farmers were asked to fill out and return data forms with individual animal data but in many instances age, breed or sex was not marked on the form. These records, summarized under the 'Unknown' category, should not present any analytic problem since farmer attention to filling out a data form for a particular animal and that animals disease status are not likely to be correlated. This lack of selection is further confirmed by the close agreement between the unknown breed or age prevalence and the overall prevalence.

The rates show large breed, age and sex differences and a female to male seropositivity ratio of approximately $3: 1$. Statistical tests of significance rule out sampling variation as an explanation of these differences (Chi-square tests; $p<0.001$ ).

Herdmate comparisons (Table 2) suggest that the low Hampshire and Suffolk prevalences are not genuine but do tend to confirm the Finn sheep high prevalence (t-test); $0.05<\mathrm{p}<0.10$ ) even though the Finn data is very sparse.

Age herdmate comparisons were computed by dividing animals in each herd into two age categories i.e. those under 1 year of age and those over 1 year of age or those under 1 year and those that are 1 or 2 years old etc. By such divisions, under 1 year old animals were compared successively to all older ages $(1+)$, to ages 1 and $2(1-2)$ etc. to age 5 or older $(5+)$. In addition, animals of age 1 or 2 years (1-2) were compared to 3 and 4 year old group (3-4) and to the 5t age group. Only herds with both age categories were used for a given comparison. The six age herdmate comparisons confirm the age trends in prevalence and indicate that prevalence rates increased with age ( $t$-test; $p<0.05$ ).

Three female-male herdmate comparisons were computed, one for adults to eliminate confounding of sex with age, one for adults with animals whose sex was unknown grouped with females and one for all ages (Table 2). All three herdmate comparisons of sex differences in prevalence were small and not statistically significant (t-test).

\section{DISCUSSION}

Herdmate comparisons which have effectively evaluated superior dairy sites based on non-random samples of daughter milk production can be used to achieve comparability within non-random sample surveys when analyzing a complex epidemiological data set. The prevalences computed by herdmate comparisons resolved several of the paradoxes seen in the "raw" prevalence rates and were biologically reasonable i.e. prevalence may be related to breed and to age but not to sex. The female-male difference in prevalence rate disappeared when comparisons were restricted to the 59 farms with females and males and age restriction did not change the picture. In this data collection, females were 
apparently more likely than males to be in high prevalence herds. Herdmate comparisons which included only those farms with both sexes eliminated confounding between sex and flock and provided an unbiased estimate of female-males difference in seroprevalence.

An average herdmate difference was computed for the several breed, age and sex comparisons by giving equal weight to each flock, even though the number of animals varied considerably among flocks. In breeding programs, a weighted average is used to compute a sire genetic value based on daughter records. The weights reflect the number of daughters in the different herdmate comparisons. For prevalence comparisons, we prefer equal weighting for each flock because the flock rather than the animal seems to be the natural unit to describe disease distribution. Weighted averages were computed in this study. They did not differ greatly from their unweighted counterparts.

\section{SUMMARY}

Non-random large scale animal disease surveys are often feasible and can provide valuable information about the factors that may influence disease prevalence. If animals can be identified by farm, the herdmate strategy used to evaluate dairy sires, can be adapted to evaluate the contributions of individual factors such as sex, age and breed to prevalence differences. 


\section{REFERENCES}

1. Cutlip, R.C., Lehmkuhl, H.D., Sacks, J.M. and Weaver, A.L., 1990. Seroprevalence of ovine progressive pneumonia virus infection in the United States. Am. J. Vet. Res. (Submitted)

2. Cutlip, R.C., Lehmkuhl, H.D., Sacks, J.M. and Weaver, A.I., 1991. Prevalence of goats with antibody to caprine arthritisencephalitis virus in the United States. J. Am. Vet. med. Assoc., Accepted June 25, 1991.

3. Henderson, C.R., Carter, H.W. and Godfrey, J.T., 1954. Use of contemporary herd average in appraising progeny tests of dairy bulls. J. Anim. Sci., 13:959. Abstract.

4. Robertson, A. and Rendel, J., 1954. The performance by heifers got by artificial insemination. J. Agric. Sci., 44:184-192.

5. The USDA-DHIA Modified Contemporary Comparison, March 1976. Sire summary and Cow Index Procedures. Agricultural Research Service, United States Department of Agriculture, production Research Report No. 165 . 
Table 1. Prevalence by breed, age and sex of ovine progressive pneumonia seropositivity in sheet.

\begin{tabular}{lrr} 
Group & $\begin{array}{c}\text { Percent } \\
\text { Positive }\end{array}$ & $\begin{array}{r}\text { Number } \\
\text { Tested }\end{array}$ \\
\hline $\begin{array}{l}\text { Overall } \\
\text { Breed } \\
\text { Finn }\end{array}$ & 26 & 16,827 \\
Hampshire & 51 & 74 \\
Suffolk & 6 & 258 \\
Other & 12 & 520 \\
Age in years & 27 & 15,975 \\
Under 1 & 4 & 3,734 \\
1-2 & 16 & 2,113 \\
3-4 & 25 & 1,015 \\
5+ & 35 & 551 \\
Unknown & 37 & 9,414 \\
Sex (adult animals) & & 11,636 \\
Female & 26 & 776 \\
Male & 8 & 4,415 \\
Unknown & &
\end{tabular}


Table 2. Breed, age and sex prevalence comparisons of ovine progressive pneumonia seropositivity between sheep and their herdmates.

\begin{tabular}{|c|c|c|c|c|c|}
\hline $\begin{array}{l}\text { Comparison } \\
\text { Group }\end{array}$ & $\begin{array}{l}\text { Number of } \\
\text { flocks }\end{array}$ & $\begin{array}{l}\text { Prevalence } \\
\text { index group }\end{array}$ & $\begin{array}{l}(q) \\
\text { Herdmates }\end{array}$ & \multicolumn{2}{|c|}{ Difference $(\mathrm{se})^{1}$} \\
\hline \multicolumn{6}{|l|}{ Breed } \\
\hline Finn & 3 & 61 & 26 & 35 & $(12)$ \\
\hline Hampshire & 10 & 20 & 18 & 02 & $(09)$ \\
\hline Suffolk & 16 & 11 & 14 & -03 & $(03)$ \\
\hline \multicolumn{6}{|l|}{ Age in years } \\
\hline Under 1 vs $1+$ & 33 & 04 & 16 & -12 & $(04)$ \\
\hline Under 1 vs $1-2$ & 26 & 05 & 10 & -05 & $(04)$ \\
\hline Under 1 vs $3-4$ & 14 & 04 & 38 & -34 & $(10)$ \\
\hline Under 1 vs $5+$ & 23 & 05 & 22 & -17 & $(05)$ \\
\hline $1-2$ vs $5+$ & 35 & 16 & 30 & -14 & $(05)$ \\
\hline \multicolumn{6}{|l|}{ sex } \\
\hline$F^{2}$ vs $M^{3}$ (adults) & 46 & 21 & 17 & 04 & (03) \\
\hline $\mathrm{F}+\mathrm{U}^{4}$ vs $\mathrm{M}$ (adults) & ) 49 & 20 & 16 & 04 & $(03)$ \\
\hline$F+U$ vs $M$ (all) & 59 & 17 & 14 & 03 & $(02)$ \\
\hline
\end{tabular}

1) the standard error of the difference

2) females

3) males

4) Unknown sex 